\title{
Occurrence of the King Nase, Chondrostoma regium (Heckel, 1843) in the Shatt Al-Arab River, Iraq
}

\author{
Abdul-Razak M. Mohamed ${ }^{1}$ and Abdullah N. Abood ${ }^{2}$ \\ 'Department of Fisheries and Marine Resources, College of Agriculture, University of Basrah, Iraq \\ ${ }^{2}$ Basrah Agriculture Directorate, Ministry of Agriculture, Iraq
}

\begin{abstract}
The occurrence of the King nase, Chondrostoma regium (Heckel, 1843) is reported for the first time from the Shatt Al-Arab River, Iraq. Four specimens of C. regium were caught by gill nets in $12^{\text {th }}$ July 2016. 25 morphometric and 16 meristic measurements were applied to describe the species. The results showed that the morphometric and meristic data were successful in identifying of $C$. regium and confirm the presence of the species in the Shatt Al-Arab River.
\end{abstract}

Keywords: King nase, morphometric and meristic characters, Shatt Al-Arab River, Iraq.

\section{Introduction}

The nases, genus Chondrostoma Agassiz, 1832 belong to the family Cyprinidae, subfamily Leuciscinae distributed from the Iberian Peninsula and France to the Caspian Sea, Esfahan and Tigris-Euphrates basins (Durand et al. 2003; Nelson, 2006; Coad, 2016). There are about 35 species of which 11 species in Turkish waters (Çiçek et al., 2015), three in Iran (Roudbar et al., 2015a, b) and one species, Chondrostoma regium in Syria and Iraq (Beckman, 1962; Jawad et al., 2015; Coad, 2010).

The King nase, C. regium (Heckel, 1843), [C. regius (Heckel, 1843), in Al-Daham (1977); Chondochilus regius Heckel, 1843, in Coad (1991)], is a subtropical fresh water fish native to Tigris-Euphrates basin in Turkey, Syria and Iraq, and their adjacent basins in Iran (Coad, 2010).

While examining the fish specimens collected from the Shatt Al-Arab River on 12th July 2016, we found four specimens of $C$. regium (Heckel, 1843), a species which has not been recorded previously from southern waters of Iraq (Khalaf, 1961; Al-Nasiri and Hoda, 1975; Al-Daham, 1977; Al-Hassan et al., 1989; Coad, 2010; Mohamed et al., 2012, 2015). Subsequently literature search has further revealed that the species has been reported from Diyala River, Iraq (Allouse et al., 1986; Khalaf et al., 1986) Tigris River at Baghdad, Iraq (Daoud and Qasim, 1999; Al-Jawda and Asmar, 2014), Dukan and Darbandikhan Reservoirs (Bachmann et al., 2008) and Tigris River, Salah Al-Deen (Wahab and Al-Ani, 2103).

Our purpose in this paper is to describe the morphometric and meristic characters of $C$. regium for the first time in the Shatt Al-Arab River, Iraq.

\section{Materials and Methods}

The confluence of the Tigris and Euphrates rivers at Qurna town, north of Basra city forms the Shatt Al-Arab River, and flows to the south east towards the Arabian Gulf. Shatt Al-Arab River has a length of 204 $\mathrm{km}$, a width range between $400 \mathrm{~m}$ at Basrah city and up to more than $1500 \mathrm{~m}$ at the estuary, and hundreds outlets in the form of small rivers and canals are found on both its sides (Al-Lami, 2009). Three tributaries flow into the river, Al-Swab River which flows from Huwaza marsh, then to the Shatt Al-Arab River at $15 \mathrm{~km}$ south of Qurna, Garmat Ali River that drains Al-Hammar marsh, and Karun River which flow through the Iranian territory and discharge into Shatt Al-Arab River, about $15 \mathrm{~km}$ south of Basrah city. The River is affected by the high and low tides of the Gulf.

On $12^{\text {th }}$ July 2016 , four specimens of $C$. regium were caught by gill nets $(100 \mathrm{~m}$ to $500 \mathrm{~m}$ with $1.5 \mathrm{~cm}$ to $15 \mathrm{~cm}$ mesh size) from the north part of Shatt Al-Arab River, near the Al-Dair bridge (Fig. 1), about 30km south of Qurna confluence. The specimens were transported to the laboratory in University of Basrah, where they were measured and weighed. 


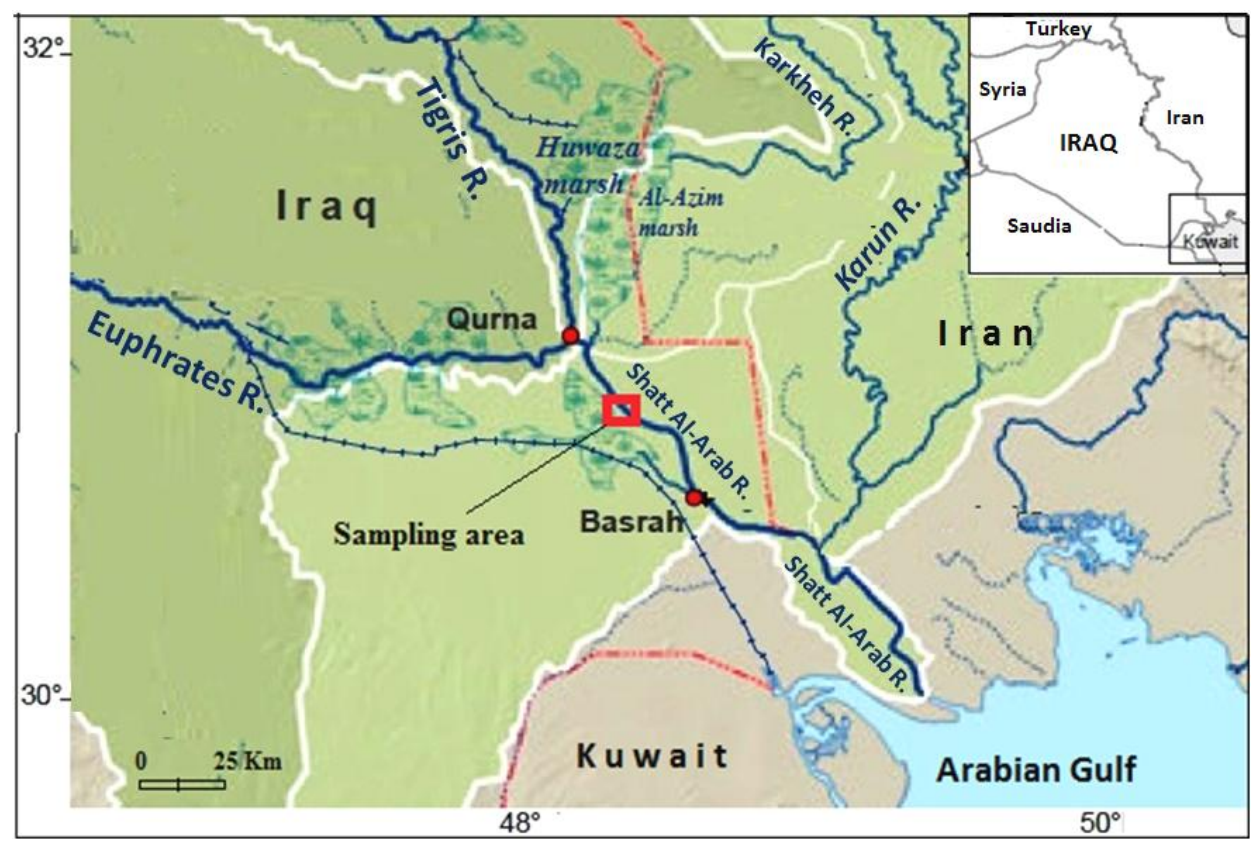

Fig. 1. Map showing the collection site of the specimens of C. regium

In the laboratory, the specimens were identified according to Beckman (1962) and Coad (2010).Twenty five morphometric and seventeen meristic characters were recorded according to Hubbs and Lagler (1964). Total, standard and fork lengths of the specimens were measured to the nearest $1.0 \mathrm{~mm}$ using a measuring board. The other morphometric variables were determined using digital caliper to the nearest $0.1 \mathrm{~mm}$. Names of morphometric and meristic characters are shown in Tables 1 and 2. The specimens were deposited in the fish collection of the Department of Fisheries and Marine Resources, College of Agriculture, University of Basrah, Iraq.

\section{Description:}

\section{Results}

C. regium is characterized by the following features. Body fusiform with a somewhat compressed (Fig. 2). The back is olive-brown with bluish reflection, silvery-white on sides and belly. Small head size compared to the body. Snout thick, round, projecting beyond the month (Fig. 3a). The mouth is transverse with a thick horny layer on the lower jaw (Fig. 3b). No barbels. Scale cycloid and small-sized. Dorsal fin origin is equaled distant from the tip of the mouth to the origin of the caudal, its rays are composed of spines and unbranced and branched rays. Pectoral fin is orange with unbranced and branched rays. Pelvic fin arises under the original of the dorsal fin with spine and unbranced and branched rays. Anal fin with spines followed by unbranced and branched rays. Caudal fin forked orange with black margin. Lateral line is closer to the belly than the back, but median in caudal peduncle.

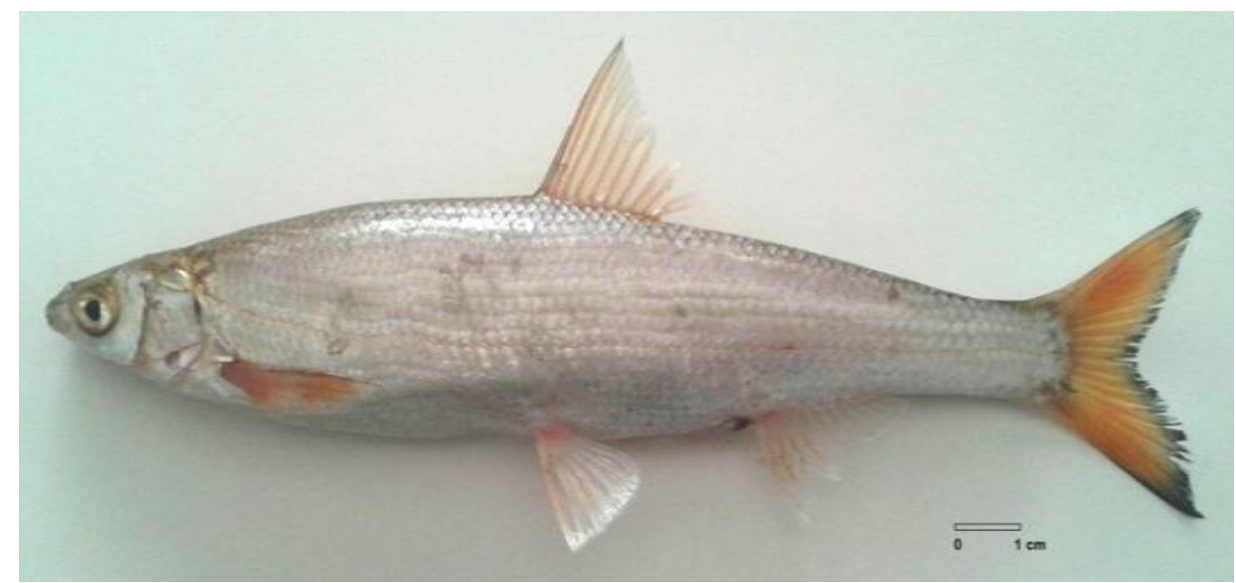

Fig. 2. C. regium captured from Shatt Al-Arab River, $225 \mathrm{~mm}$ total length 


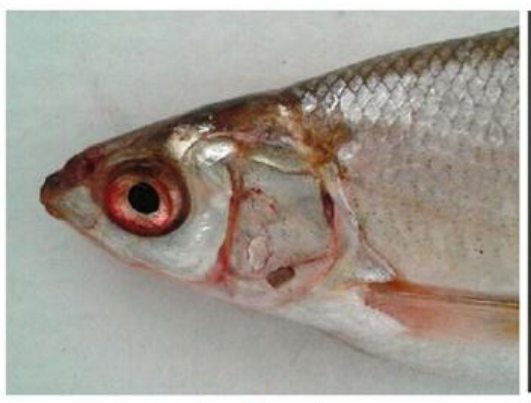

(a) Snout

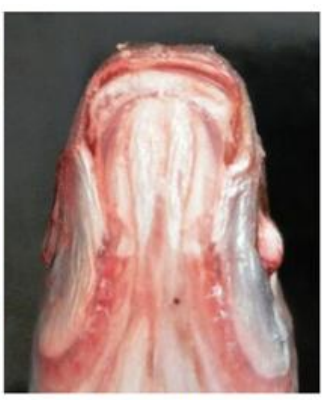

(b) Mouth

Fig. 3. Snout and mouth in C. regium, $184 \mathrm{~mm} \mathrm{TL}$

\section{Morphometric characters:}

All specimens of $C$. regium were ranging from 170 to $225 \mathrm{~mm}$ in total length (TL) and 23.7 to $43.2 \mathrm{~g}$ in total weight using for the studies of the morphometric characters. Different morphometric characters which are expressed in the percentage of standard fish length and head length have been taken for statistical analysis like range, mean and standard deviation, and presented in the Table 1.The mean indices characters varied from $3.7 \%$

Table 1. Biometric characteristic (\%) of Chondrostoma regium from Shatt Al-Arab River, Iraq

\begin{tabular}{|l|c|c|}
\hline Morphometric characteristics $(\mathrm{n}=4)$ & Range & Mean $( \pm \mathrm{SD})$ \\
\hline Related characters in \% of SL & & \\
\hline Total length & $119.7-132.4$ & $124.7(5.43)$ \\
\hline Forked length & $107.7-112.2$ & $110.1(2.13)$ \\
\hline Head length (HL) & $18.7-20.1$ & $19.6(0.61)$ \\
\hline Body depth & $23.8-24.7$ & $24.3(0.37)$ \\
\hline Body width & $12.1-13.5$ & $12.7(0.62)$ \\
\hline Head depth & $12.9-13.9$ & $13.3(0.45)$ \\
\hline Head width & $10.6-11.0$ & $10.7(0.16)$ \\
\hline Snout length & $4.5-5.2$ & $4.7(0.31)$ \\
\hline Interorbital distance & $7.2-7.7$ & $7.5(0.20)$ \\
\hline Eye diameter & $5.3-5.5$ & $5.4(0.10)$ \\
\hline Upper jaw length & $3.1-4.2$ & $3.7(0.46)$ \\
\hline Mouth width & $4.7-5.1$ & $4.85(0.14)$ \\
\hline Predorsal length & $47.2-48.3$ & $47.9(0.52)$ \\
\hline Dorsal-fin base length & $11.9-13.5$ & $12.7(0.70)$ \\
\hline Dorsal fin length & $17.8-21.1$ & $19.7(1.39)$ \\
\hline Anal fin length & $14.9-17.3$ & $16.6(1.13)$ \\
\hline Preanal length & $67.6-72.1$ & $69.8(2.54)$ \\
\hline Prepelvic length & $47.5-51.8$ & $50.0(1.94)$ \\
\hline Prepectoral length & $19.4-20.8$ & $20.4(0.69)$ \\
\hline Anal-fin base length & $12.5-13.6$ & $13.1(0.44)$ \\
\hline Pectoral fin length & $16.1-17.9$ & $17.4(0.88)$ \\
\hline Pelvic fin length & $13.8-16.7$ & $15.5(1.23)$ \\
\hline Caudal peduncle length & $19.7-21.6$ & $20.6(0.79)$ \\
\hline Caudal peduncle depth & $9.5-10.1$ & $9.9(0.31)$ \\
\hline Related characters in \% of HL & & \\
\hline Head depth & $64.3-74.3$ & $67.9(4.45)$ \\
\hline Head width & $53.7-56.8$ & $54.7(1.47)$ \\
\hline Snout length & $22.1-27.5$ & $24.1(2.40)$ \\
\hline Interorbital distance & $35.8-39.8$ & $38.2(1.71)$ \\
\hline Eye diameter & $27.2-28.0$ & $27.6(0.34)$ \\
\hline Upper jaw length & $15.6-21.3$ & $19.1(2.71)$ \\
\hline
\end{tabular}

of upper jaw length to $124.7 \%$ of total length. The mean ratio of head length was $19.6 \%$ in standard length. However, the ratio of body depth (19.6\%) was greater than the ratio of body width (10.7\%). The indices characters of different parts of head with head length ranged from $19.1 \%$ of upper jaw length to $67.9 \%$ of head depth (Table 1).

\section{Meristics characters:}

The meristic characters data of $C$. regium with length range of 170 to $225 \mathrm{~mm}$ in TL are presented in Table 2. The results were pharyngeal teeth 6-6, 7-7 and 6-6 (Fig. 4a), gill rakers 34-36 (Fig. 4b), vertebrae 46-48 (Fig. 4c), lateral line scales 65-71, scales above the lateral line 9-12 and scales below the lateral line 5-6. Dorsal fin with 2 spines, 1 unbranched and 9 branched rays. Pectoral fin with 1 unbranched and 15-17 branched rays. 
Pelvic fin with 1 spine, 1 unbranched and 8 branched rays. Anal fin with 3 spines, 10-11 unbranched and 8 branched rays.

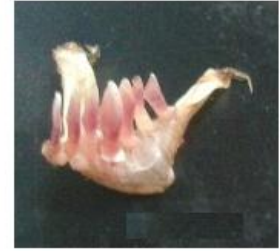

(a) Pharyngeal teeth

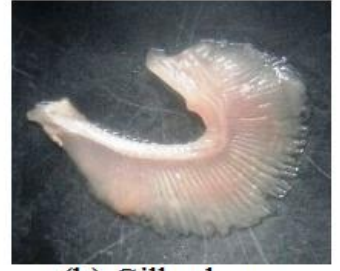

(b) Gill rakers

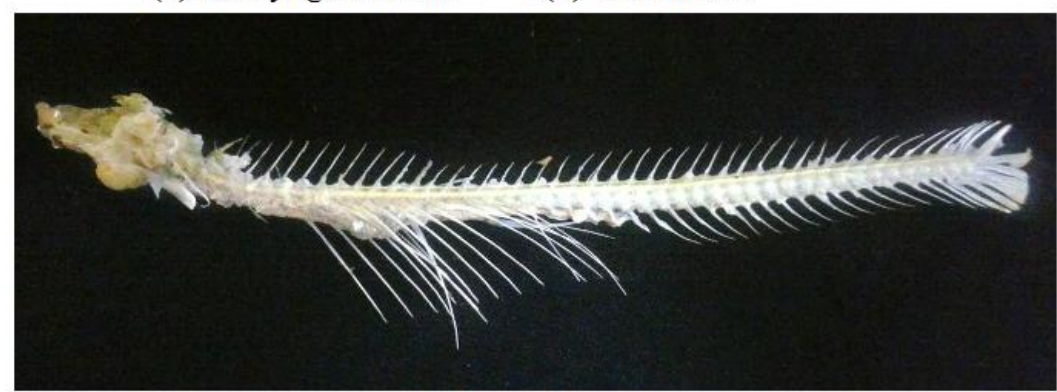

(C) Vertebral column

Fig.4. Pharyngeal teeth, gill rakers and vertebral column bone in C. regium, $184 \mathrm{~mm}$ TL

Table 2. Comparison of biometric characteristics of C. regium from Shatt Al-Arab River with other studies.

\begin{tabular}{|c|c|c|c|c|c|}
\hline Biometric characteristics & $\begin{array}{c}\text { Present } \\
\text { study }\end{array}$ & $\begin{array}{l}\text { Khalaf } \\
(1961)\end{array}$ & $\begin{array}{c}\text { Beckman } \\
(1962)\end{array}$ & $\begin{array}{c}\text { Al-Daham } \\
(1977)\end{array}$ & Coad (2010) \\
\hline Body depth in \% of SL & $24-25$ & $23-25$ & $23-25$ & $23-25$ & \\
\hline Head length in $\%$ of SL & $19-20$ & $20-22$ & $21-22$ & $22-23$ & \\
\hline Eye diameter in $\%$ of $\mathrm{HL}$ & $27-28$ & $20-25$ & $20-25$ & & \\
\hline Lateral line scales & $65-71$ & & $64-68$ & $64-68$ & $56-72$ \\
\hline Scales above the lateral line & $9-12$ & & & 11 & $9-13$ \\
\hline Scales below the lateral line & $5-6$ & 5 or 6 & 5 & 5 & $5-6$ \\
\hline Branched rays of dorsal fin & $9-9$ & & 9 & 9 & $8-11(9)$ \\
\hline Branched rays of pectoral fin & $15-17$ & & & $16-17$ & $14-18(15-17)$ \\
\hline Branched rays of pelvic fin & $8-8$ & & & 9 & 6-9 (8) \\
\hline Branched rays of anal fin & $10-11$ & & $10-11$ & $10-11$ & $9-12(11)$ \\
\hline Unbranched rays of anal fin & $1-1$ & & & & \\
\hline Anal fin spine & $3-3$ & & 3 & & \\
\hline Gill rakers & $34-36$ & & & & $18-36$ \\
\hline Vertebrae & $46-48$ & & & & $46-49$ \\
\hline Pharyngeal teeth & $6-6,7-7$ & 6 or 7 & $7-7,7-6,6-6$ & $7-7,6-7,6-6$ & $6-5,6-6,6-7,7-5,7-6,7-7$ \\
\hline
\end{tabular}

\section{Discussion}

Previous studies on the ichthyofauna in the Shatt Al-Arab River did not indicate the presence of $C$. regium in this river (Al-Nasiri and Hoda, 1975; Al-Hassan et al., 1989; Mohamed et al., 2012, 2015), while the fish taxonomy references affirmed that $C$. regium is found in the Tigris upstream and tributaries (Khalaf, 1961; Al-Daham, 1977; Coad, 2010). Some other researchers reported this species in Diyala River (Allouse et al., 1986; Khalaf et al., 1986) and in Tigris River (Daoud and Qasim, 1999; Wahab and Al-Ani, 2013). Also, this species is relatively widespread in Tigris River basin of Iran includes the Karkheh River and the Al-Azim marsh, which connects to Huwaza marsh to drain into the Tigris River and the Shatt al Arab River, and the Karun River, which drains into the Shatt Al-Arab River (Roudbar et al., 2015a; Coad, 2016).

Thus, from a mere geographical point of view, its presence was to be expected in the Shatt Al-Arab River, particularly this year which characterized by heavy floods, either from Tigris River from the north or from Iranian rivers from the east. Hence, the capture of $C$. regium reported herein is the first from the Shatt $\mathrm{Al}$ Arab River.

The biometrical study of $C$. regium has not been investigated in Iraq, therefore the morphometric and meristic characteristics of $C$. regium in the Shatt Al-Arab River were compared with data obtained from some taxonomy references (Table 2). The results showed that meristic features of $C$. regium agree with the description of this species given by Khalaf (1961), Beckman (1962), Al-Daham (1977) and Coad (2010). The only exceptions were slight differences in some morphometric characteristics, such as head length and eye diameter. Roudbar et al. (2014) found highly significant morphological variations among eight $C$. regium populations in 
different aquatic ecosystems from western Iran, due to different environmental and habitat conditions, such as temperature, turbidity, food availability, and water depth. Peres-Neto and Magnan (2004) stated that morphometric characters varied according to the changing environmental conditions of the habitat throughout their life and the phenotypic plasticity have been shown in many freshwater fish species.

\section{Conclusions}

The results showed that the morphometric and meristic data were successful in identifying of $C$. regium and confirm the presence of the species in the Shatt Al-Arab River.

\section{References}

[1]. J.D. Durand, P.G. Bianco, J. Laroche, and A. Gilles, Insight into the origin of endemic Mediterranean ichthyofauna: Phylogeography of Chondrostoma genus (Teleostei, Cyprinidae). J. Heredity, 94(4), 2003, 315-328.

[2]. J.S. Nelson, Fishes of the world (John Wiley \& Sons, 2006).

[3]. B.W. Coad, Freshwater fishes of Iran (www.briancoad.com, accessed 31 May 2016).

[4]. E. Çiçek, S.S. Birecikligil, and R. Fricke, Freshwater fishes of Turkey: a revised and updated annotated checklist. Biharean Biologist. 9 (2), 2015. 141-157.

[5]. A.J. Roudbar, H.R. Esmaeili, A. Gholamhosseini, R. Zamanian, and S.Vatandoust, Geographic distribution of the genus Chondrostoma Agassiz, 1832 in Iran (Teleostei: Cyprinidae). Iran. J. Ichthyol., 2(2), 2015a, 71-78.

[6]. A.J. Roudbar, S. Vatandoust, S. Eagderi, S.J. Kenari, and H.M. Sabet, Freshwater fishes of Iran; an updated checklist. AACL Bioflux 8, 2015b, 855-909.

[7]. W.C. Beckman, The freshwater fishes of Syria and their general biology and management (FAO Fisheries biology branch Technical Paper, 8, 1962).

[8]. L. Jawad, D. Bobori, H. Al-Shwikh, and F. Al-Saleh, Opercular girth, maximum girth and total length relationships for Planiliza abu (Heckel, 1843) and Chondrostoma regium (Heckel, 1843) (Actinoprerygii) from Euphrates River at Dier Ez-Zor Governorate, Syria. Acta Zool. Bulgaria, 67(4), 2015, 591-594.

[9]. B.W. Coad, Freshwater fishes of Iraq (Pensoft Publishers, Sofia, Bulgaria, 2010).

[10]. N.K. Al-Daham, Fish of Iraq and the Arab Gulf (Vol. 1, Baghdad, Al-Irshad Press, 1977).

[11]. B.W. Coad, Fishes of the Tigris-Euphrates, Basin: A critical checklist (Canadian Museum of Nature, Ichthyology sections. Syllogeus No. 98, 1991).

[12]. K.T. Khalaf, The marine and fresh water fishes of Iraq (Al-Rabitta Press, Baghdad, 1961).

[13]. S.K. Al-Nasiri, and S.M.S. Hoda, Survey of fish fauna of Shatt Al-Arab (from Abu-al-Khasib to Karmat Ali). Bull. Basrah Nat.

[14]. Hist. Mus., 2, 1975, 36-46.

[15]. L.A.J. Al-Hassan, N.A Hussain, and K.D. Soud, A preliminary annotated check-list of the fishes of Shatt Al-Arab River River, Basrah, Iraq. Pol. Arch. Hydrobiol. J., 36, 1989, 283-288.

[16]. A.R.M. Mohamed, A.K. Resen, and M.M. Taher, Longitudinal patterns of fish community structure in the Shatt Al-Arab River,

[17]. Iraq. Basrah J. Sci., 30, 2012, 65-86.

[18]. A.R.M. Mohamed, S.A. Hussein, and L.F. Lazem, Spatiotemporal variability of fish assemblage in the Shatt Al-Arab River, Iraq. J. Coast. Life Med., 3(1), 2015, 27-34.

[19]. S. B. Allouse, A. N. Khalaf, and A. Al-Jafary, Some biological aspects of Chondrostoma regius (sic) (Heckel) - (Cyprinidae: Cypriniformes) in Diyala River (Baghdad-Iraq). J. Biol. Sci. Res., Baghdad, 17(1), 1986, 227-239.

[20]. A. N. Khalaf, A. Al-Jafery, S.B. Allouse, and Sadek, S.E. Observations on the age and growth of Chondrostoma regius (sic) (Heckel) in Diyala River. J. Biol. Sci. Res., Baghdad, 17(2), 1986, 83-98.

[21]. H.A.M. Daoud, and H. Qasim, Some observations on the biology of Chondrostoma regium (Heckel) from Tigris River. Ibn AlHaitham J. Pure \& Appl. Sci., 10(2), 1999, 1-9.

[22]. J.M. Al-Jawda, and K.R. Asmar, A second collection of myxosporeans (phylum Myxozoa) parasitic on some fishes from Tigris River at Baghdad Province, Iraq. Am. J. Biol. Life Sci., 2(6), 2014, 198-202

[23]. A. Bachmann, C.R. Dela Cruz, J. Davies, and L.R. Malone, Key Biodiversity Survey of Kurdistan, Northern Iraq. Nature Iraq, Sulaimani, Iraq. Publ. No. NI-1208-001, 2008, 120p.

[24]. N.K. Wahab, and S.M.H. Al-Ani, Some biological aspects of some fishes from Eastern Drainge/Balad, Iraq. Diyala Agr. Sci. J., 5, 2013, 1-15.

[25]. O.R.T. Al-Lami, 2009. Some marine properties for Arabian Gulf on north part's hydrology of Shatt Al-Arab Riverbed. MSc thesis. Basrah University, Basrah, Iraq.

[26]. C.L. Hubbs, and K.F. Lagler, 1964. Fishes of the Great Lakes Region. University of Michigan Press, Ann Arbor, xv, 213p, 44 pls

[27]. A.J. Roudbar, H. Rahmani, H.R. Esmaeili, and S.Vatandoust, Morphological variations among Chondrostoma regium populations in the Tigris River drainage. AACL Bioflu, 7, 2014, 279-285.

[28]. P.R. Peres-Neto, and P. Magnan, The influence of swimming demand on phenotypic plasticity and morphological integration: a comparison of two polymorphic charr species. Oecologia 140(1), 2004, 36-45. 